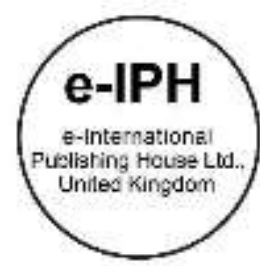

\title{
Benefits and Challenges of Heritage Building Information Modelling Application in Malaysia
}

\author{
Elma Dewiyana Ismail 1, Shahrul Yani Said 1, Mohd Khairul Anuar Jalil 1, Noor Akmal Adillah Ismail 2 \\ ${ }^{1}$ Centre of Studies for Building Surveying, Faculty of Architecture, Planning and Surveying, Universiti Teknologi MARA, Shah Alam, \\ Selangor, 41450, Malaysia \\ ${ }^{2}$ Centre of Studies for Quantity Surveying, Faculty of Architecture, Planning and Surveying, Universiti Teknologi MARA, Shah Alam, \\ Selangor, 41450, Malaysia
}

dewiyana@uitm.edu.my, shahrulyani@uitm.edu.my, khairul2432@uitm.edu.my, noorakmal@uitm.edu.my

Tel of $1^{\text {st }}$ Author: +60 16-944 9904

\begin{abstract}
Studies revealed that most heritage buildings in Malaysia are deteriorating due to poor maintenance of recorded documentation. Unfortunately, conserving heritage buildings is a complex and multi-layered process that requires collaboration between different stakeholders. Heritage Building Information Modeling (HBIM) is seen as an opportunity to establish a well-managed data collection. This paper attempts to examine the awareness, benefits and challenges of the implementation of BIM among stakeholders. Sixty-nine respondents with BIM knowledge and skills answered the questionnaire. Findings show significant attributes that could improve building conservation project performance, delivery and management, hence several challenges that need further improvement.
\end{abstract}

Keywords: Building Information Modeling, Conservation, Heritage building information modelling

eISSN: 2398-4287@ 2021. The Authors. Published for AMER ABRA cE-Bs by e-International Publishing House, Ltd., UK. This is an open access article under the CC BYNC-ND license (http://creativecommons.org/licenses/by-nc-nd/4.0/). Peer-review under responsibility of AMER (Association of Malaysian Environment-Behaviour Researchers), ABRA (Association of Behavioural Researchers on Asians/Africans/Arabians) and CE-Bs (Centre for Environment-Behaviour Studies), Faculty of Architecture, Planning \& Surveying, Universiti Teknologi MARA, Malaysia.

DOI: https://doi.org/10.21834/ebpj.v6iSI4.2917

\subsection{Introduction}

Building Information Modeling (BIM) is one of the advanced processes used in the construction industry. The building data gathered for BIM incorporates both geometric information and non-geometric information. The application of BIM enables us to visualize production of teamwork, improved data reliability, insightful documentation, dispersed access and recovery of building information and high-quality project result through improved performance analysis, and in addition multidisciplinary arranging and coordination. It is one of the essential territories in the era of Virtual Reality (VR). It enables technology to condense all the information required during the building works process in one single file, creating what has been called "smart" models.

Studies have been carried out on the implementation of advanced technology to act as a tool for conservation work. Initially, Building Information Modeling (BIM) is used in the construction industry. This technology method applies and preserves an integral digital representation of all building information for various periods of the task life span as an information store (Rogers, Chong, \& Preece, 2015). Historic Building Information Modeling (HBIM) is the evolution of BIM for heritage buildings. In Malaysia, the adoption of BIM and HBIM are relatively low and slow (Ali, Ismail, Has-Yun, Suhaimi, \& Mustafa, 2018; Rogers et al., 2015). This paper discusses the benefit and challenges of HBIM application in Malaysia. This study focuses on examining the awareness, benefits and challenges of the implementation of BIM among stakeholders.

eISSN: 2398-42870 2021. The Authors. Published for AMER ABRA CE-Bs by e-International Publishing House, Ltd., UK. This is an open access article under the CC BYNC-ND license (http://creativecommons.org/licenses/by-nc-nd/4.0). Peer-review under responsibility of AMER (Association of Malaysian Environment-Behaviour Researchers), ABRA (Association of Behavioural Researchers on Asians/Africans/Arabians) and CE-Bs (Centre for Environment-Behaviour Studies), Faculty of Architecture, Planning \& Surveying, Universiti Teknologi MARA, Malaysia.

DOI: https://doi.org/10.21834/ebpj.v6iSI4.2917 
In Malaysia, HBIM is not being considered as part of the submission for Conservation Permission by the Jabatan Warisan Negara (JWN). Looking at how comprehensive the model is, it is a loss if HBIM was not introduced in this field. The objectives of the studies are to assess the level of readiness of the stakeholders to use HBIM and to analyze the benefits and challenges in HBIM application in conservation projects in Malaysia.

\subsection{Historic Building Information Modeling (HBIM)}

Dr Maurice Murphy introduced HBIM at the Dublin Institute of Technology. It is a method for modelling historic structures from laser scan and photogrammetric information using BIM programming. The technique incorporates the arrangement of parametric objects representing architectural elements that are often mapped onto laser scan or photogrammetric survey information. The HBIM process begins with the remote collection of survey data using a terrestrial laser scanner combined with digital cameras. A range of software programs is then used to combine the image and scan data. A library of parametric architectural objects from historical manuscripts and architectural pattern books are installed using scripting language within the BIM programming called Geometric Descriptive Language (GDL). They are then joined and mapped onto the survey information to form the whole model. The technology has made it possible to capture every single detail on a building.

Some of the benefits of HBIM are:

1. It accurately records complex and hidden structures that may not be conceivable with past survey methods.

2. It allows the project to store and archive information of any historic building, materials used, description of work regarding an element or components of the building, semantics for building elements, manufacturers detail and dimension of building components (Ali, M., Ibrahim, M. N., Mohd Yunus, R., Yahya, M. R., Ismail, F., Mohd Din, A, \& Ibrahim, 2017),

3. The computerized data can perform multiple building analyses,

4. It generates a building model that contains exact geometry and related information of the building,

5. It allows continuity of information sharing among stakeholders.

There are several challenges in implementing HBIM for building conservation projects. As the HBIM technology is still a new process, there are insufficient experts to execute the project using HBIM. Furthermore, computer gadgets and technology equipment are expensive tools and require high investment. Personnel handling HBIM should be well trained with new technological skill sets such as 3D modelling expertise, understanding of the survey approach, collaboration and communication with other industry players that are involved in the project. There is less number of conserved heritage buildings as the projects are more complicated and have a higher risk compared to new building projects. People are less committed and aware of historic buildings conservation.

\subsection{HBIM application for Malaysian building heritage conservation projects}

Building heritage conservation is a sensitive task, as there are many issues that have to be considered (Zahirah, Azizi, Abdul, Azizi, \& Din, 2016). Although there are only 183 buildings that have been gazetted as a national heritage in Malaysia (Ali et al., 2018), it is crucial for us to protect and preserve the traditions and heritage (Mohd Yusoff, Dollah, Anwar, \& Din, 2010). The limited number of gazette heritage buildings with significant values in Malaysia is due to deterioration issues (Al-Obaidi, K.M. and Wei, S.L. and Ismail, M.A. and Kam, 2017). There are a lot of complicated processes for heritage conservation projects. Before the project starts, prior information about the building and surroundings needs to be researched and analyzed. Some of the vital information includes the building's history, its historical layers, material characterization and properties, damage and temporal decay. Accurate information is required to achieve a successful conservation or renovation project for a heritage building. However, studies showed that several building conservation works encountered inaccurate project information, insufficient documentation, poor maintenance, lack of technology adaptation, and poor reports reliability (Ali et al., 2018). The conservation projects still adopt the conventional method using papers, pictures, and reports as the main output. Building submission to the local authority is seldom carried out (Ali et al., 2018).

\subsection{Difference of HBIM and BIM}

HBIM is said to be the evolution of BIM. In Malaysia, BIM's role is defined as a modelling technology and associated set of processes to produce, communicate, analyze and use digital information models throughout the construction project life cycle (CIDB, n.d.). BIM is a new technology usually used in new constructions. It has the capability to retain different information in different formats, such as tables, graphs, images, texts, links, etc. It also allows having a holistic view of the building. There are many benefits of BIM related to financial, better information, communication and coordination, response to complexity, improved visual, improved sustainability, improved safety and also create service's or business's opportunities (Boeykens \& Neuckermans, 2008). Although BIM technology has been well received by the Malaysian construction industry theoretically, the application rate is still slow (Wan Mohammad, Abdullah, Ismail, \& Takim, 2018).

HBIM is often used in the design and construction phases rather than in post-construction, such as during maintenance or occupancy. There has been an increasing interest in applying the concepts and technologies of BIM to heritage buildings. However, there are several evident differences between BIM and HBIM (lan J. Ewart \& Zuecco, 2019). Heritage buildings usually have a long history of use, reuse and alteration. The aim of managing the building is often related to conservation rather than occupancy. There is often a social and community resource involved. Thus, HBIM has a different set of stakeholders from the BIM users. 


\subsection{Methodology}

Reviews of literature survey became the backbone of this study. As this is a pilot study, only 100 selected stakeholders who are BIM users or familiar with BIM were approached. Respondents included consultants, contractors, and facility management personnel, academicians and built environment students in the Klang Valley area. A preliminary questionnaire survey was distributed to 100 respondents as the primary data gathering technique. Judgment sampling was used on the basis of assessing the respondent's awareness and knowledge in HBIM and building conservation projects. The inclusion criteria for selecting respondents were (i) Experience in BIM usage, (ii) Knowledge of building conservation projects. It is important that the respondents have adequate knowledge and prior information on BIM to answer the questionnaire. Useful feedback from these experienced stakeholders will inform the outlook of the HBIM application for a heritage conservation project in Malaysia. The respondents were asked about (i) their awareness of the application of HBIM for historical conservation projects and (ii) their knowledge of HBIM application.

The questionnaires were either distributed via post, email or by hand. A total of 69 responses were returned, giving a success rate of $69 \%$. The questionnaire was divided into three sections. The first section is on demographic information, the second section is on the awareness of the application of HBIM for historical conservation projects, and the last section is on the issues of HBIM. The questionnaire mainly uses the Likert Scale of five ordinal measures from one (1) to five (5) ascending the level of agreement. The average index for each question was calculated using the formula: Average index $=\sum \mu \mathrm{Xn} / \mathrm{n}$.

\subsection{Findings}

Based on Fig. 1, 36.2\% ( $n=25)$ often use BIM software followed by $30.4 \%(n=21)$ respondents who use BIM sometimes. Most of the respondents are familiar and have used BIM software. In Fig. 2, 49.3\% ( $n=34$ ) used Autodesk Revit. The second highest is 29.0\% ( $n=20)$ using ArchiCAD and $17.4 \%(n=12)$ uses both Autodesk Revit and ArchiCAD. There are also other respondents who use other BIM software such as Bentley and Sketchup.

Most of the respondents agree and strongly agree that HBIM could further improve on the project implementation and provide accurate data and information that would be easier to retrieve and shared. It would also benefit the maintenance stage, enhance energy efficiency and reduce safety risks and wastage.

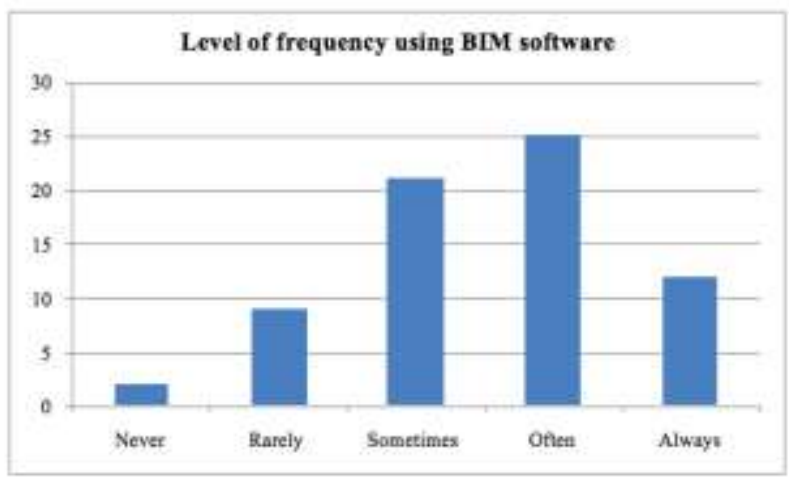

Fig. 1: Level frequency using BIM software

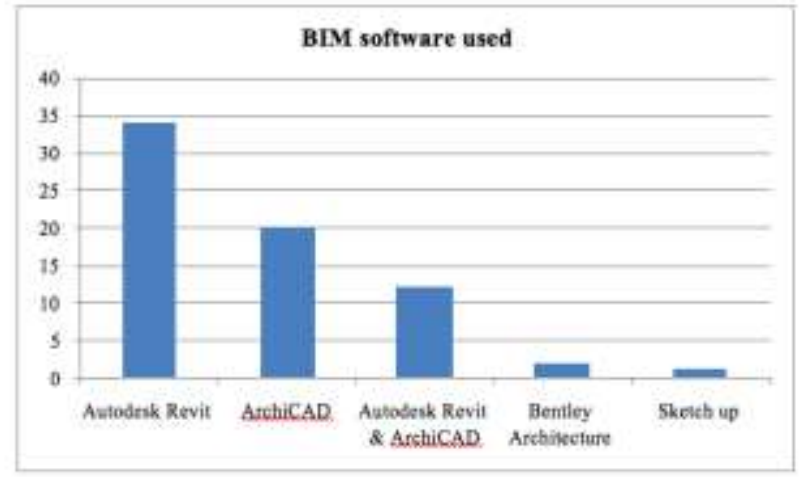

Fig. 2: BIM software used

Table 1 shows that there are many benefits in implementing BIM in building conservation project management. The respondents agree that a digital system and integrated HBIM could produce an accurate 2D image of to-scale drawing at any stage of work for reference (average index 4.14). As it can be assessed by all parties using only one source, it helps to reduce conflicts in the on-site decision, and the data provide accurate design visualization that assists all parties. Besides that, other benefits of BIM is that BIM has the ability to improve the management of documentation, enhance safety and security information management and also enhance energy efficiency and sustainability of the building. With these benefits, BIM could be seen as an advantage in producing a smooth project.

Table 1. Other benefits of BIM implementation for building conservation project management

\begin{tabular}{|l|l|c|}
\hline \multicolumn{1}{|c|}{$\begin{array}{c}\text { Ranking } \\
\text { Opinion }\end{array}$} & \multicolumn{1}{|c|}{ Other Benefits } & $\begin{array}{c}\text { Average } \\
\text { Index }\end{array}$ \\
\hline 1 & Generation of accurate and consistent 2D drawings at any stage & 4.14 \\
\hline 2 & Improved conflicts detection & 4.09 \\
\hline 3 & Earlier and more accurate design visualization & 4.07 \\
\hline 4 & Improved coordination and communication in the construction phase & 4.05 \\
\hline 5 & & 4.03 \\
\hline 6 & The use of BIM improves conservation work & 4.03 \\
\hline
\end{tabular}




\begin{tabular}{|l|l|l|}
\hline 7 & Potential improved maintenance of the facility due to the as-built model & 4.01 \\
\hline 8 & Enhanced team collaboration & 3.99 \\
\hline 9 & Improved document management & 3.99 \\
\hline 10 & Greater predictability of project time and cost & 3.96 \\
\hline 11 & Potential improved whole life asset management & 3.96 \\
\hline 12 & Allows accurate site logistics plans & 3.94 \\
\hline 13 & Allows increased energy analysis of the building & 3.94 \\
\hline 14 & Fewer change orders at the conservation stage & 3.91 \\
\hline 15 & Enhanced management of security and safety information & 3.86 \\
\hline 16 & Efficiencies from reuse of data (enter once use many) & 3.83 \\
\hline 17 & Enhanced energy efficiency and sustainability of the building & 3.78 \\
\hline 18 & Reduced safety risks & 3.72 \\
\hline 19 & Reduced waste & 3.71 \\
\hline 20 & Improved human resources management & 3.7 \\
\hline 21 & Easy to identify architectural style detail & 3.68 \\
\hline 22 & Reduced defect issues & 3.48 \\
\hline
\end{tabular}

\subsection{Challenges Of HBIM Application For Conservation Projects}

Respondents were also asked about their opinions regarding any challenges in implementing HBIM. In Table 2, respondents opined that the cost to purchase the software, training and cost of model copyright might become barriers that hinder the successful implementation of HBIM. Purchasing the new technology cost a lot, and it may become a major reason to delay implementing HBIM. Personnel who handle HBIM should effectively manage information across all stages of the construction projects. Thus, they need training courses that provide the most relevant and up-to-date information in the market. In Table 3, training involves cost and also time is taken to enable the personnel to be more experts.

Table 2: Barriers on cost for the implementation of HBIM

\begin{tabular}{|l|l|l|}
\hline $\begin{array}{l}\text { Ranking } \\
\text { Opinion }\end{array}$ & Barriers On Cost & Average Index \\
\hline 1 & Cost of new software and updates & 4.07 \\
\hline 2 & Cost of training existing staff & 3.99 \\
\hline 3 & Cost of model copyright & 3.99 \\
\hline 4 & Use high technology equipment & 3.94 \\
\hline 5 & Client limitation due to the high cost & 3.83 \\
\hline
\end{tabular}

Table3. Challenges due to time and training phase for HBIM

\begin{tabular}{|l|l|l|}
\hline $\begin{array}{l}\text { Ranking } \\
\text { Opinion }\end{array}$ & Challenges Due To Time And Training Phase & Average Index \\
\hline 1 & Appropriate training and information on the use of HBIM must be provided & 4.02 \\
\hline 2 & Lack of HBIM training & 4.01 \\
\hline 3 & Time required to train existing staff & 3.96 \\
\hline 4 & Time required to produce the models & 3.94 \\
\hline 5 & Time is taken to implement HBIM & 3.94 \\
\hline
\end{tabular}

There are also other challenges that may effects management and administration for any HBIM project (Table 4). A lot of changes involving the organization's organizational structure, document compatibility, the collaboration between different industry players, working culture, adaptability and new technology are amongst the top issues that need to be examined.

Table 4: Challenges due to management and administration issues for HBIM

\begin{tabular}{|l|l|l|}
\hline $\begin{array}{l}\text { Ranking } \\
\text { Opinion }\end{array}$ & Management And Administration & Average Index \\
\hline 1 & Restructuring of the organization to accommodate HBIM & 4 \\
\hline 2 & The need that digital design data be compatible & 3.99 \\
\hline
\end{tabular}




\begin{tabular}{|c|c|c|}
\hline 3 & The need for suitable data sharing standards & 3.97 \\
\hline 4 & The unsuitability of some projects to the adoption of HBIM & 3.97 \\
\hline 5 & Immaturity of software in terms of data exchange and interoperability & 3.97 \\
\hline 6 & Lack of skilled personnel & 3.97 \\
\hline 7 & Culture change towards fully collaborative working & 3.97 \\
\hline 8 & Lack of expertise and experience worker & 3.96 \\
\hline 9 & Lack of efficient contractual documentation & 3.93 \\
\hline 10 & Inadequate information available to the supply chain & 3.91 \\
\hline 11 & People refusal/reluctance to learn & 3.91 \\
\hline 12 & Client-driven limitations, e.g. due to unawareness of HBIM benefits & 3.91 \\
\hline 13 & Lack of high technology equipment & 3.91 \\
\hline 14 & Need a lot of professional bodies involved & 3.9 \\
\hline 15 & The steep learning curve for those unfamiliar with the technology & 3.9 \\
\hline 16 & The need for well-defined commercial business process models & 3.9 \\
\hline 17 & The need to define role model manager for projects & 3.9 \\
\hline 18 & The need to draft HBIM specific contracts & 3.88 \\
\hline 19 & Undefined responsibilities for the data content & 3.88 \\
\hline 20 & Huge amount of documentation to deal & 3.86 \\
\hline 21 & Inadequate support available to the supply chain & 3.86 \\
\hline 22 & Unauthorized reuse of intellectual properties & 3.86 \\
\hline 23 & Lack of clear boundary of responsibilities between parties & 3.86 \\
\hline 24 & Client limitation due to the high cost & 3.83 \\
\hline 25 & Lack of staff that can use high technology equipment & 3.81 \\
\hline 26 & Unawareness of benefits HBIM can bring to the organization & 3.78 \\
\hline 27 & Unavailable technology equipment & 3.7 \\
\hline 28 & Unawareness of benefits HBIM can bring to the project & 3.68 \\
\hline 29 & Unable to identify the material used directly & 3.58 \\
\hline 30 & Unable to identify architecture style directly & 3.45 \\
\hline
\end{tabular}

\subsection{Conclusion}

HBIM is a way forward in building conservation work in Malaysia. Literature studies suggest there are many benefits documented in the literature for the implementation of HBIM in building conservation projects. Although the system seems to be one of the best approaches for managing data and driving the decision-making process, in Malaysia, the adoption of BIM and HBIM are relatively minimal. There are several challenges that need to be addressed. Application of HBIM demands well-trained personnel with new skill sets and good collaboration with the other industry players to ensure any building conservation projects to be successful. Due to this matter, training and hands-on BIM should be provided for those related to project design and management. However, it is anticipated that HBIM technology may be used for more types of projects in the future due to encouragement by the current government for the usage of integrated construction data through BIM and Artificial Intelligence (AI). HBIM could further improve on the valuable authenticity of Malaysian history and building architecture conservation project implementation from rapid destruction. The use of HBIM in the documentation and conservation phases will support an integrated database system for heritage buildings that help in understanding the buildings and conservation works carried out when referred to in future.

\section{Acknowledgements}

The authors gratefully acknowledge the help of the Institute of Research Management \& Innovation (IRMI), Universiti Teknologi MARA (UiTM) for funding this research through the Lestari Research Grant: 600-IRMI/MYRA 5/3/LESTARI (K) (236/2017)

\section{References}

Al-Obaidi, K.M. and Wei, S.L. and Ismail, M.A. and Kam. (2017). Sustainable Building Assessment of Colonial Shophouses after Adaptive Reuse in Kuala Lumpur. Buildings, 7(4), 87. 
Ali, M., Ibrahim, M. N., Mohd Yunus, R., Yahya, M. R., Ismail, F., Mohd Din, A, \& Ibrahim, M. S. (2017). Exploring methods of quantity measurement for heritage conservation works. Journal of Computational and Theoretical Nano science, 23(7), 6277-6280.

Ali, M., Ismail, K. M., Has-Yun, K. S., Suhaimi, S., \& Mustafa, M. H. (2018). Historic Building Information Modeling (HBIM) For Malaysian Construction Industry. Planning Malaysia: Journal of the Malaysian Institute of Planners, 16(3), 332-343.

Boeykens, S., \& Neuckermans, H. (2008). Representational limitations and improvements in Building Information Modeling. In M. Muylle (Ed.), eCAADe 26 (pp. 35-42). eCAAADe. Retrieved from http://cumincad.scix.net/data/works/att/ecaade2008_024.content.pdf

CIDB. (n.d.). BIM. Retrieved from http://www.cidb.gov.my/index.php/en/services/scoreapplication/2-uncategorised/704-bim

Ian J. Ewart, \& Zuecco, V. (2019). Heritage Building Information Modeling (HBIM): A Review of Published Case Studies. In H. T. (eds) Mutis I. (Ed.), Advances in Informatics and Computing in Civil and Construction Engineering. Springer, Cham. http://doi.org/https://doi.org/10.1007/978-3-030-00220-6_5

Mohd Yusoff, Y., Dollah, H., Anwar, M., \& Din, O. (2010). Pembangunan Warisan di Malaysia : Tinjauan Umum Tentang Dasar Pengenalan. Jurnal Melayu, (5), $277-283$.

Rogers, J., Chong, H.-Y., \& Preece, C. (2015). Adoption of Building Information Modelling technology (BIM): Perspectives from Malaysian engineering consulting services firms. Engineering, Construction and Architectural Management, 22(4), 424-445. http://doi.org/10.1108/ECAM-05-2014-0067

Wan Mohammad, W. N. S., Abdullah, M. R., Ismail, S., \& Takim, R. (2018). Overview of Building Information Modeling ( BIM ) adoption factors for construction organizations. IOP Conference Series: Earth and Environmental Science, 140. http://doi.org/https://doi.org/10.1088/1755-1315/140/1/012107

Zahirah, N., Azizi, M., Abdul, A., Azizi, M., \& Din, M. (2016). Recurring Issues in Historic Building Conservation. In Procedia - Social and Behavioural Sciences (Vol. 222, pp. 587-595). http://doi.org/10.1016/j.sbspro.2016.05.217 